\title{
CORRELATION BETWEEN OBESITY, SAGITTAL BALANCE AND CLINICAL OUTCOME IN SPINAL FUSION
}

\author{
CORRELAĈ̃O ENTRE OBESIDADE, EQUILÍBRIO SAGITAL E RESULTADO CLÍNICO \\ EM ARTRODESE DA COLUNA VERTEBRAL
}

CORRELACIÓN ENTRE OBESIDAD, EQUILIBRIO SAGITAL Y RESULTADO

CLIINICO EN LA ARTRODESIS ESPINAL

Marcel Machado da Motta', Raphael Rezende Pratali1, Marcela Almeida Campos Coutinho ${ }^{1}$, Carla Balkany Hoffman',

Carlos Eduardo Gonç̧ales Barsotti', Francisco Prado Eugênio dos Santos ${ }^{1}$, Carlos Eduardo Algaves Soares de Oliveira ${ }^{1}$

\begin{abstract}
Objective: To correlate obesity with radiographic parameters of spinal and spinopelvic balance in patients undergoing spinal arthrodesis, and to correlate obesity with clinical outcome of these patients. Methods: Observational retrospective study including patients who underwent spinal arthrodesis, with minimum follow-up period of three months. We measured waist circumference, as well as height and weight to calculate body mass index (BMI) and obtained radiographs of the total column. The clinical parameters studied were pain by visual analog scale (VAS) and the Oswestry questionnaire (ODI). Obesity correlated with radiographic parameters of the sagittal and spinopelvic balance and postoperative clinical parameters. Results: 32 patients were analyzed. The higher the BMI, the greater the value of VAS found, but without statistical significance $(p=0.83)$. There was also no correlation between BMI and the ODI questionnaire. Analyzing the abdominal circumference, there was no correlation between the VAS and ODI. There was no correlation between BMI or waist circumference and the radiographic parameters of global spinopelvic sagittal alignment. Regarding the postoperative results, there was no correlation between the mean BMI and waist circumference and the postoperative results for ODI and VAS ( $p=0.75$ and $p=0.7$, respectively). Conclusions: The clinical outcomes of patients who undergone spinal fusion were not affected by the BMI and waist circumference. Also, there was no correlation between radiographic parameters of spinal and spinopelvic sagittal balance with obesity in patients previously treated with arthrodesis of the spine.
\end{abstract}

Keywords: Spine fusion; Obesity; Postural balance; Pelvis; Low back pain.

\section{RESUMO}

Objetivo: Correlacionar a obesidade com os parâmetros radiográficos do equilíbrio sagital espinhal e espinopélvico em pacientes submetidos à artrodese da coluna vertebral, além de correlacionar a obesidade com o resultado clínico de tais pacientes. Métodos: Estudo observacional, retrospectivo, que incluiu pacientes submetidos a artrodese da coluna vertebral, com período de seguimento mínimo de três meses. Medimos a circunferência abdominal, assim como a altura e o peso, para o cálculo do índice de massa corporal (IMC) e obtivemos radiografias da coluna total. Os parâmetros clínicos estudados foram: dor pela escala visual analógica (EVA) e o questionário de Oswestry (ODI). Correlacionamos obesidade com os parâmetros radiográficos do equilíbrio sagital e espinopélvico e com os parâmetros clínicos pós-operatórios. Resultados: Foram analisados 32 pacientes. Quanto maior o IMC, maior foi o valor da EVA encontrado, porém sem significância estatística $(p=0,83)$. Também não houve correlação entre o IMC e o questionário ODI. Analisando a circunferência abdominal, não houve correlação com EVA ou ODI. Não houve correlação entre IMC ou circunferência abdominal e os parâmetros radiográficos do alinhamento sagital e espinopélvico. Quanto ao resultado pós-operatório, não houve correlação entre as médias do IMC e da circunferência abdominal e o resultado pós-operatório pelo ODI e pela EVA ( $p=0,75$ e $p=0,7$, respectivamente). Conclusões: Os resultados clínicos de pacientes submetidos a artrodese da coluna vertebral não foram alterados pelo IMC e pela circunferência abdominal. Também não se observou correlação entre os parâmetros radiográficos do equilíbrio sagital espinhal e espinopélvico com a obesidade em pacientes previamente submetidos a cirurgia de artrodese da coluna vertebral.

Descritores: Fusão vertebral; Obesidade; Equilíbrio postural; Pelve; Dor lombar.

\section{RESUMEN}

Objetivo: Correlacionar la obesidad con los parámetros radiográficos del equilibrio sagital vertebral y espinopélvico en pacientes sometidos a artrodesis vertebral y correlacionar la obesidad con la resultado clínico de estos pacientes. Métodos: Estudio observacional y retrospectivo que incluyó pacientes sometidos a la artrodesis de la columna vertebral con un período de seguimiento mínimo de tres meses. Se midió la circunferencia de la cintura, así como la altura y el peso para calcular el índice de massa corporal (IMC) y se obtuvo radiografías de la columna total. Los parámetros clínicos estudiados fueron el dolor mediante la escala visual analógica (EVA) y el cuestionario de Oswestry (ODI). La obesidad fue correlacionada con los parámetros radiográficos del balance sagital y espinopélvico y parámetros clínicos postoperatorios. Resultados: Se analizaron 32 pacientes. Cuanto mayor sea el índice de masa corporal, mayor será el valor de EVA, pero sin significación estadística ( $p=0,83)$. Tampoco hubo correlación entre el IMC y el cuestionario ODI. Analizando la circunferencia abdominal, no hubo correlación con EVA u ODI. No hubo correlación entre el IMC o la circunferencia de la cintura y los parámetros radiográficos de la alineación sagital y espinopélvica. En cuanto el resultado postoperatorio, no hubo correlación entre la media de IMC y la circunferencia de la cintura y los resultados postoperatorios por el ODI o EVA ( $p=0,75$ y $p=0,7$, respectivamente). Conclusiones: Los resultados clínicos

1. Hospital do Servidor Público Estadual, Department of Orthopedics andTraumatology, São Paulo, SP, Brazil. 
de pacientes sometidos a la artrodesis de la columna vertebral no se vieron afectados por el IMC y la circunferencia de la cintura. Además no había correlación entre los parámetros radiográficos del equilibrio sagital de la columna y el espinopélvico con la obesidad en pacientes previamente tratados con artrodesis de la columna vertebral.

Descriptores: Fusión lumbar; Obesidad; Balance postural; Pelvis; Dolor de la región lumbar.

\section{INTRODUCTION}

Obesity, which currently reaches epidemic proportions, is characterized by absolute or relative excess of body fat. ${ }^{1,2}$ The most highly recommended method for assessing body weight is through the Body Mass Index (BMI)., ${ }^{3,4}$ The measurement of the waist circumference reflects the visceral fat content and is also related to total body fat. ${ }^{5}$

Obesity affects the whole body and can lead to countless complications, including degenerative orthopedic and spinal diseases. 2,6 Body fat distribution interferes directly in the obese patient's body alignment, promoting an overload and predisposing to the appearance of postural deviations. ${ }^{7}$ Moreover, muscle hypotrophy can occur as a result of the accumulation of adipose tissue in the abdomen (central body fat), leading to weakness of the stabilizing muscles of the spine and contributing to the appearance of lumbar instability in the obese individual. ${ }^{8}$ Considering these changes in obese individuals, we can deduce that there may be changes in the sagittal balance of these patients. ${ }^{4}$

For many years, spinal alignment has been assessed only in the coronal plane, yet many publications have highlighted the importance of changes in the sagittal plane. The relationship between the spine and changes in pelvic orientation, and how they determine overall vertebral alignment, has also been studied. ${ }^{9-11}$

In the sagittal plane, we can regard the vertebral column as a linear chain that links the head to the pelvis, where the shape and the orientation of each anatomical segment are closely related and influence the adjacent segment to maintain a stable posture with minimum energy expenditure. ${ }^{12}$ Low back pain following arthrodesis has shown itself to be significantly related to decreased sacral slope, increased pelvic tilt and decreased lumbar lordosis, regardless of other factors, such as pseudarthrosis. ${ }^{13}$

Despite numerous studies linking obesity to several diseases, there are few studies correlating postural changes of the trunk with this pathology, besides the influence that excess weight can exert on spinal pathologies. The relationship between obesity and sagittal spinal and spinopelvic balance ${ }^{4}$ and how such changes can interfere in the surgical outcome of individuals undergoing spinal arthrodesis is not well understood either.

The objectives of this study were to evaluate and correlate obesity with the sagittal parameters of sagittal spinal and spinopelvic balance in a group of patients undergoing spinal fusion surgery, besides correlating obesity with the clinical and functional outcome of such patients.

\section{METHODS}

This is an observational, retrospective study approved by the IRB of the department where it was conducted (opinion no. 682.079), which involved patients who had previously undergone thoracolumbar and lumbosacral spinal fusion, with a minimum postoperative follow-up time of three months. All the procedures were carried out in the same department and by the same team. Patients with degenerative spinal disease, including degenerative lumbar spondylolisthesis, adult scoliosis, lumbar herniated disc, and lumbar canal stenosis were included in the study, while patients with primary or secondary spinal neoplastic disease and congenital or traumatic pathologies were excluded.

The patients underwent a full-spine radiographic examination, including the base of the skull and the femur heads, in the upright position, with fingers positioned on the clavicle with shoulder at 45 degrees of elevation. ${ }^{14}$ The scanned images obtained were analyzed using the Surgimap Spine software (Nemaris Inc., New York, USA), to measure the following radiographic parameters of overall sagittal and spinopelvic alignment: Sagittal vertical axis (SVA), sacral slope (SS), pelvic tilt (PT), pelvic incidence (PI), thoracic kyphosis (TK), and lumbar lordosis (LL), as illustrated in Figure 1.

All the patients had their waist circumference, height and weight measured to calculate the BMI. To measure the waist circumference, we used a non-extendable measuring tape with the patient in a relaxed standing upright posture. The parameters were the midpoint between the lower costal margin and anterior superior iliac spine. ${ }^{15}$

We used the table proposed by the World Health Organization (WHO) to classify excess weight and obesity according to the BMI. The following values were used: normal weight: BMI between 20 and 25; Pre-obese, 25 to 29.9; Obese class I 30 to 34.9; Obese class II 35 to 39.9; Obese class III $\geq 40$. We also used the values determined by WHO to classify the waist circumference. For men: Increased waist circumference, if $\geq 94 \mathrm{~cm}$ and substantially increased if $\geq 102 \mathrm{~cm}$. For women these values are 80 and $88 \mathrm{~cm}$, respectively. ${ }^{16,17}$

For functional evaluation we used the visual analog scale (VAS) of pain and the Oswestry Disability Index (ODI) questionnaire adapted and validated for the Portuguese language. ${ }^{18,19}$ The visual analog scale of pain is graded from 0 to 10 , where 0 is equivalent to absence of pain and 10 the strongest pain that the patient has ever experienced. In the functional evaluation through the ODI, the patient receives a score referring to everyday activities, such as: Presence of pain, personal care, ability to lift weights and sleeping. In the preoperative period the results are stratified in minimum incapacity, moderate incapacity, intense incapacity, incapacitated and disabled. The ODI also can be used to assess the postoperative result according to the functional incapacity measured, which can be classified as excellent, good, unchanged or worsened.

The normality of variables was tested by the Shapiro Wilk test, associations were tested by Pearson's Chi-squared test and the quantitative variables were tested using the Student's t-test. To compare means between groups we used the ANOVA test for the parametric data and the Kruskal Wallis test for nonparametric data. To measure the degree of correlation between variables, Pearson's correlation coefficient was used for the parametric data and Spearman's rank correlation coefficient for the nonparametric data.

A significance level of $5 \%$ was used in all the case, thus those whose $p$ value was below 0.05 were considered statistically significant.

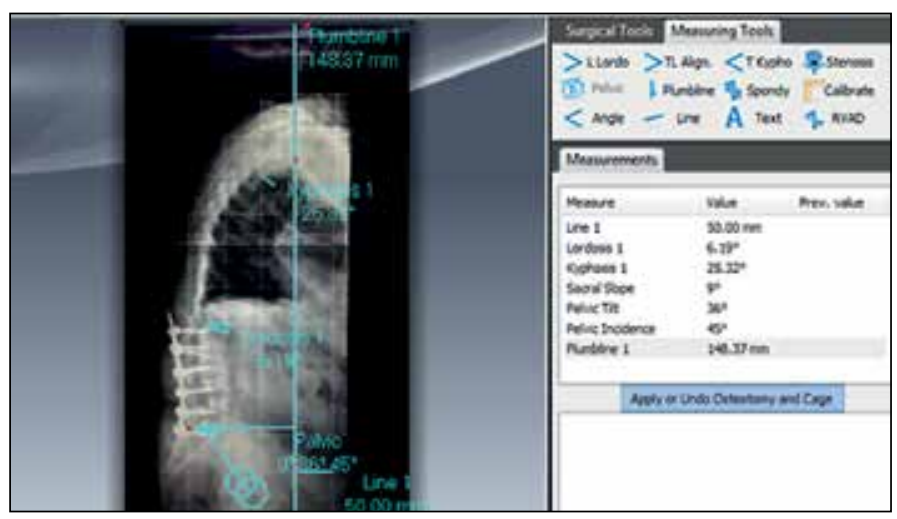

Figure 1. Example of scanned image with measurements of the radiographic parameters of interest (SVA, PI, SS, PT, LL and TK) using Surgimap Spine software (Nemaris Inc., New York, USA) 


\section{RESULTS}

We analyzed 32 patients that undergoing lumbar arthrodesis, with average follow-up time of 22 months, ranging between 3 and 68 months. Seven patients had follow-up between 3 and 12 months and another variables six between 12 and 24 months. The sample contained 10 male and 22 female patients. There was no significant difference between gender distribution in the prevalence of the surgical procedure $(p=0.14)$.

The mean BMI was 29, ranging from 20 to 40.8. As illustrated in Table 1, in analyzing the BMl with regards to gender, it can be noted that the women present a higher mean than the men, yet without statistical significance $(p=0.14)$. Ten patients $(31.3 \%)$ were considered normal, nine patients $(28.1 \%)$ were overweight, nine were graded with obesity class I (28.1\%), three with obesity class II (9.4\%) and one with obesity class III (3.1\%).

The mean waist circumference was $97.7 \mathrm{~cm}$, ranging from 82 to $115.5 \mathrm{~cm}$. As illustrated in Table 2, in analyzing waist circumference by gender, it can be noted that the women presented a higher mean than the men, yet without statistical significance $(p=0.34)$.

Table 3 presents the mean values of VAS, of ODI, the radiographic variables and their correlation with the classification according to the BMI. Note that the higher the BMI, the greater the VAS found, yet without statistical significance $(p=0.83)$. The other variables did not present correlations.

Table 4 presents the mean values of VAS, of ODI, the radiographic variables and their correlation with the classification according to waist circumference. No statistically significant correlations were found in any of the parameters analyzed.

Table 5 shows the distribution of patients with regards to the postoperative outcome of the degree of functional incapacity according to the ODI. Note that $53.2 \%$ presented excellent or good results, while $40.6 \%$ were unchanged and $6.3 \%$ presented worsening of functional capacity. Table 6 shows the distribution of patients with regards to postoperative pain intensity according to VAS. Note that $18.8 \%$ con-

Table 1. Relationship between gender and BMI.

\begin{tabular}{c|c|c|c|c}
\hline Gender & $\mathbf{n}^{\circ}(\%)$ & Mean (sd) & Median (min-max) & $\mathbf{p}$ \\
\hline Male & $10(31)$ & $27.0(3.56)$ & $26.4(22.6-32,4)$ & 0.14 \\
\hline Female & $22(69)$ & $29.9(5.61)$ & $29.6(20.9-40,8)$ & \\
\hline Total & $32(100)$ & $29.0(5.19)$ & $28.1(20.0-40,8)$ & \\
\hline
\end{tabular}

Body Mass Index (BMI)

Table 2. Relationship between gender and waist circumference.

\begin{tabular}{c|c|c|c|c}
\hline Gender & $\mathbf{n}^{\circ}(\%)$ & Mean $(\mathbf{s d})$ & Median (min-max) & $\mathbf{p}$ \\
\hline Male & 10 & $95.6(7,1)$ & $93.5(88-104.5)$ & 0.34 \\
\hline Female & 22 & $98.7(8,9)$ & $100(82-115.5)$ & \\
\hline Total & 32 & $97.7(8,3)$ & $98.5(82-115.5)$ & \\
\hline
\end{tabular}

Table 3. Relationship between the parameters of sagittal balance and BMI.

\begin{tabular}{c|c|c|c|c|c|c}
\hline \multirow{2}{*}{$\begin{array}{c}\text { Mean of } \\
\text { variables }\end{array}$} & Normal & Overweight & $\begin{array}{c}\text { First-degree } \\
\text { obesity }\end{array}$ & $\begin{array}{c}\text { Second- } \\
\text {-degree } \\
\text { obesity }\end{array}$ & $\begin{array}{c}\text { Third- } \\
\text {-degree } \\
\text { obesity }\end{array}$ & $\mathbf{p}$ \\
\hline SVA & 60.6 & 52.1 & 38.9 & 58.8 & -16.9 & 0.66 \\
\hline SS & 34.7 & 36.3 & 32.7 & 31.3 & 36.0 & 0.95 \\
\hline PT & 22.0 & 17.8 & 22.2 & 19.7 & 21.0 & 0.88 \\
\hline PI & 59.2 & 53.7 & 55.0 & 50.7 & 57.0 & 0.69 \\
\hline TK & 37.0 & 40.2 & 35.3 & 31.3 & 27.0 & 0.79 \\
\hline LL & 46.6 & 45.2 & 41.6 & 31.5 & 55.0 & 0.74 \\
\hline
\end{tabular}

Body Mass Index (BMI), Sacral slope (SS), Pelvic tilt (PT), Pelvic incidence (PI), Thoracic kyphosis (TK), Lumbar lordosis (LL). sidered their pain mild, $53.1 \%$ moderate and $28.1 \%$ intense. Table 7 , in turn, shows mean BMI and waist circumference values, distributed with regards to the classification of the postoperative outcome by ODI and pain by VAS. There was no significant difference between means according to the classes of ODI and of VAS.

Table 4. Relationship between the parameters of sagittal balance and waist circumference.

\begin{tabular}{c|c|c|c|c}
\hline \multirow{2}{*}{$\begin{array}{c}\text { Mean of } \\
\text { variables }\end{array}$} & \multicolumn{4}{|c}{ Waist circumference } \\
\cline { 2 - 5 } & Normal & Increased & Substantially increased & $\mathbf{p}$ \\
\hline SVA & 67.8 & 23.9 & 47.9 & 0.34 \\
\hline SS & 39.2 & 34.5 & 33.3 & 0.34 \\
\hline PT & 17.4 & 23.0 & 21.1 & 0.53 \\
\hline PI & 56.6 & 57.5 & 55.2 & 0.84 \\
\hline TK & 31.6 & 40.0 & 37.3 & 0.97 \\
\hline LL & 42.8 & 45.5 & 43.7 & 0.85 \\
\hline
\end{tabular}

Sacral slope (SS), Pelvic tilt (PT), Pelvic incidence (PI), Thoracic kyphosis (TK), Lumbar lordosis (LL).

Table 5. Values by category of the Oswestry questionnaire, in the postoperative evaluation.

\begin{tabular}{c|c|c}
\hline Oswestry & $\mathbf{n}$ & $\%$ \\
\hline Excellent & 2 & 6.3 \\
\hline Good & 15 & 46.9 \\
\hline Unchanged & 13 & 40.6 \\
\hline Worsening & 2 & 6.3 \\
\hline Total & 32 & 100 \\
\hline
\end{tabular}

Table 6. Values by VAS category in the postoperative evaluation.

\begin{tabular}{c|c|c}
\hline VAS & $\mathbf{n}$ & $\%$ \\
\hline Mild & 6 & 18.8 \\
\hline Moderate & 17 & 53.1 \\
\hline Intense & 9 & 28.1 \\
\hline Total & 32 & 100 \\
\hline
\end{tabular}

Visual Analog Scale (VAS).

Table 7. Relationship between the postoperative categories of VAS and ODI with the BMI and waist circumference.

\begin{tabular}{l|c|c|c|c|c}
\hline \multirow{2}{*}{\multicolumn{2}{c|}{ Patient evaluation }} & \multicolumn{2}{c|}{ BMI } & \multicolumn{2}{c}{ Waist circumference } \\
\cline { 3 - 6 } \multicolumn{2}{c}{} & $\begin{array}{c}\text { Mean } \\
\text { values }\end{array}$ & $\mathbf{p}$ & $\begin{array}{c}\text { Mean } \\
\text { Values }\end{array}$ & $\mathbf{p}$ \\
\hline OSWESTRY & \multicolumn{5}{|c}{} \\
\hline & Excellent & 24.8 & 0.37 & 96.3 & 0.75 \\
\hline & Good & 29.2 & & 97.8 & \\
\hline \multirow{2}{*}{} & Unchanged & 30.1 & & 98.2 & \\
\hline & Worsening & 24.8 & & 95 & \\
\hline \multirow{2}{*}{ VAS } & Mild & 27.6 & 0.26 & 96.2 & 0.70 \\
\hline & Moderate & 29.5 & & 97.8 & \\
\hline & Intense & 29.0 & & 98.5 & \\
\hline
\end{tabular}

Body Mass Index (BMI), Visual Analog Scale (VAS).

\section{DISCUSSION}

Studies of the correlation between obesity and clinical and functional outcome following spinal fusion surgery are scarce in literature. However, some studies have demonstrated that there is no significant difference between postoperative results in normal, 
obese and morbidly obese patients. ${ }^{20,21}$ In the study by Djurasovic et al., ${ }^{20}$ despite the higher rate of complications in obese patients, mainly surgical site infection, the rate of postoperative clinical improvement was similar to that presented by the non-obese patients.

There was not considered rate of complications with the different degrees of obesity in the present study. However, the results presented do not demonstrate a significant correlation between postoperative clinical outcome (measured through VAS and ODI) and the obesity indicators (BMI and waist circumference), which is similar to the result described in the literature. The postoperative outcome was considered good or excellent by $53.2 \%$ of the patients, yet without correlation with the BMI or with waist circumference.

As regards the correlation of radiographic parameters of sagittal spinal and spinopelvic balance with obesity, results showing a correlation between such parameters can be found in literature. Araujo et al., ${ }^{22}$ in 2014, showed that the BMI and waist circumference are related to increased pelvic tilt and pelvic incidence. Kulcheski et al., ${ }^{4}$ in 2013, showed that pelvic incidence and pelvic tilt values are higher in the obese than in the population with normal BMI, and found similar sacral slope values.

The results obtained in the current study did not demonstrate significant correlation between the radiographic parameters analyzed and the obesity indicators, as described in the literature. However, unlike the other studies, we considered only patients undergoing spinal fusion surgery, which hinders the comparison between our results and those published in the literature, since spine fusion, especially when instrumented with pedicle screws, can significantly change the relationship between the physiological curves of the vertebral column and the pelvis. ${ }^{13,24,25}$

The main limitation of the study lies in the fact that it is retrospective and we do not have the functional evaluation parameters (VAS and ODI) in the preoperative period, which would allow an analysis of the improvement of function instead of the end result, besides a pairing of patients by degree of pain and functional incapacity. Another point was the considerable discrepancy in the follow-up time, where two patients were assessed less than six months postoperatively and another eight patients between six and twelve months, a time considered short for the establishment of arthrodesis consolidation.

\section{CONCLUSIONS}

The clinical and functional outcomes of patients undergoing spinal fusion were not changed by the BMI and by the waist circumference. No correlation was noted between the radiographic parameters of sagittal spinal and spinopelvic balance with obesity either.

All authors declare no potential conflict of interest concerning this article.

\section{REFERENCES}

1. World Health Organization (WHO). Global strategy on diet, physical activity and health 2004. [Acess: 05/08/2014]. Aviable from: http://www.who.int/E1D27D19-2D4E-480BAC96 D1B76C1705A5/FinalDownload/Downloadld05D226B92CBC9BBA214C7A48D09430B5/E1D27D19-2D4E-480B-AC96D1B76C1705A5/dietphysicalactivity/strategy/ eb11 344 /strategy_english_web.pdf.

2. Ribeiro MRF, Moisés RS. Obesidade: como diagnosticar e tratar. Rev Bras Med. 2006;63:143-52.

3. Coutinho W. Obesidade: conceitos e classificação. In: Nunes MA, Abuchaim ALG, Appolinario JC, organizadores. Transtornos alimentares e obesidade. Porto alegre: Artmed; 2002. p. 197-202.

4. Kulcheski AL, Graells XS, Benato ML, Baretta G. Avaliação angular do equilíbrio sagital em pacientes obesos. Coluna/Columna. 2013;12(3):224-7.

5. Ribeiro MRF, Moisés RS. Obesidade: como diagnosticar e tratar. Rev Bras Med. 2006;63:143-52.

6. Faintuch J, Ribeiro Júnior N, Rodrigues JG. Epidemiologia e comorbidades da obesidade. Rev Bras Nutr Clín. 2005;20(1):16-9.

7. Pondofe KM, Andrade MC de Meyer PF Silva EM. Relação entre força abdominal, abdome protuso e ângulo lombossacral em mulheres jovens. Fisioter Mov. 2006;19(4):99-104.

8. Demoulin C, Distrée V, Tomasella M, Crielaard JM, Vanderthommen M. Lumbar functional instability: a critical appraisal of the literature. Ann Readapt Med Phys. 2007:50(8):677-84

9. Duval-Beaupère G, Robain G. Visualization on full spine radiographs of the anatomical connections of the centres of the segmental body mass supported by each vertebra and measured in vivo. Int Orthop. 1987;11(3):261-9.

10. Itoi E. Roentgenographic analysis of posture in spinal osteoporotics. Spine (Phila Pa 1976). 1991;16(7):750-6.11

11. Henneman AS, Antoneli PHL, Oliveira GC. Incidência pélvica: um parâmetro fundamental para definição do equilíbrio sagital da coluna vertebral. Coluna/Columna. 2012:11(3):237-9

12. Berthonnaud E, Dimnet J, Roussouly P, Labelle H. Analysis of the sagittal balance of the spine and pelvis using shape and orientation parameters. J Spinal Disord Tech. 2005;18(1):40-7.

13. Lazennec JY, Ramaré S, Arafati N, Laudet CG, Gorin M, Roger B, et al. Sagittal alignment in lumbosacral fusion: relations between radiological parameters and pain. Eur Spine J. 2000;9(1):47-55.
14. Horton WC, Brown CW, Bridwell KH, Glassman SD, Suk SI, Cha CW. Is there an optimal patient stance for obtaining a lateral $36^{\prime \prime}$ radiograph? A critical comparison of three techniques. Spine (Phila Pa 1976). 2005:30(4):427-33.

15. Sociedade Brasileira de Hipertensão; Sociedade Brasileira de Cardiologia; Sociedade Brasileira de Endocrinologia e Metabologia; Sociedade Brasileira de Diabetes; Sociedade Brasileira de Estudos da Obesidade. I Brazilian guidelines on diagnosis and treatment of metabolic syndrome. Arq Bras Cardiol. 2005;84(Suppl 1):1-28

16. Ribeiro-Filho FF, Faria AN, Kohlmann NE, Zanella MT, Ferreira SR. Two-hour insulin determination improves the ability of abdominal fat measurement to identify risk for the metabolic syndrome. Diabetes Care. 2003;26(6):1725-30.

17. Carneiro G, Faria AN, Ribeiro Filho FF, Guimarães A, Lerário D, Ferreira SR, et al. Influence of body fat distribution on the prevalence of arterial hypertension and other cardiovascular risk factors in obese patients. Rev Assoc Med Bras. 2003;49(3):306-11.

18. Fairbank JC, Pynsent PB. The Oswestry Disability Index. Spine (Phila Pa 1976) 2000:25(22):2940-52

19. Vigatto R, Alexandre NM, Correa Filho HR. Development of a Brazilian Portuguese version of the Oswestry Disability Index: cross-cultural adaptation, reliability, and validity. Spine (Phila Pa 1976) .2007:32(4):481-6.

20. Djurasovic M, Bratcher KR, Glassman SD, Dimar JR, Carreon LY. The effect of obesity on clinical outcomes after lumbar fusion. Spine (Phila Pa 1976). 2008;33(16):1789-92.

21. Vaidya R, Carp J, Bartol S, Ouellette N, Lee S, Sethi A. Lumbar spine fusion in obese and morbidly obese patients. Spine (Phila Pa 1976). 2009;34(5):495-500.

22. Araújo F, Lucas R, Alegrete N, Azevedo A, Barros H. Individual and contextual characteristics as determinants of sagittal standing posture: a population-based study of adults. Spine J. 2014;14(10):2373-83

23. Gödde $S$, Fritsch $E$, Dienst $M$, Kohn D. Influence of cage geometry on sagittal alignment in instrumented posterior lumbar interbody fusion. Spine (Phila Pa 1976). 2003;28(15):1693-9

24. Goldstein JA, Macenski MJ, Griffith SL, McAfee PC. Lumbar sagittal alignment after fusion with a threaded interbody cage. Spine (Phila Pa 1976). 2001;26(10):1137-42.

25. Stephens GC, Yoo JU, Wilbur G. Comparison of lumbar sagittal alignment produced by different operative positions. Spine (Phila Pa 1976). 1996;21(15):1802-6. 